Herz 2017 · 42:255-261

DOI 10.1007/s00059-016-4531-4

Published online: 24 March 2017

CrossMark (c) Springer Medizin Verlag GmbH 2017

\author{
A. Colclough ${ }^{1,2} \cdot$ P. Nihoyannopoulos ${ }^{1,3}$ \\ 'Imperial College Healthcare Trust, St Mary's Hospital, Paddington, London, UK \\ ${ }^{2}$ Emergency Department, Kings College Hospital, Denmark Hill, London, UK \\ ${ }^{3}$ Hammersmith Hospital, London, UK
}

\section{Pocket-sized point-of-care cardiac ultrasound devices}

\section{Role in the emergency department}

\section{Introduction}

Acute breathing difficulties are the cause of $8 \%$ of emergency calls and are the third ranking emergency call presentation [1, 2].

Diagnosing the cause of respiratory symptoms in patients can be a diagnostic challenge due to the wide range of disease processes and the number of systems involved. Causes include primary lung or cardiac conditions, shock or metabolic causes. To confuse the clinician further the aetiology may be multifactorial and therefore treating the wrong cause may exacerbate the condition [4]. We know from autopsy studies that misdiagnosis occurs in $30-50 \%$ of patients $[4,5]$ and improvements need to be made.

Obtaining an accurate diagnosis in an emergency department can be delayed by waiting for diagnostic tests such as $\mathrm{B}$-natriuretic peptide assays, chest X-rays or CT pulmonary angiograms. Departmental echocardiography is rarely readily available and departments are under huge strain. Point-of-care cardiac ultrasound can be very useful in these scenarios.
Echocardiography in the emergency department is a well-established technique $[3,6,7]$, but its use is not as common in everyday practice as it might be. It has been shown that FoCUS echocardiography can be a valuable tool for rapid assessment in the emergency department where predefined clinical questions can be answered with a limited number of views by noncardiologist operators $[6,8,9]$. Pocketsized echocardiography is increasingly used by cardiologists when reviewing patients with diagnosed or suspected acute coronary syndrome and with the management of a wider range of chronic conditions in less acute inpatient settings. Pocket-sized devices are convenient, becoming more affordable and image quality is rapidly improving to a standard that their use is now widespread.

Currently there is no established recommendation for performing echocardiography in patients presenting with breathlessness, although its efficacy for the diagnosis of several conditions has previously been demonstrated [10] with a suggestion that this should be become part of good clinical practice. At present

\section{Table 1 NHS triage categories [13]}

\begin{tabular}{|c|c|}
\hline $\begin{array}{l}\text { National } \\
\text { codes }\end{array}$ & \\
\hline 1 & $\begin{array}{l}\text { Immediate resuscitation: patients in need of immediate treatment for preservation of } \\
\text { life }\end{array}$ \\
\hline 2 & Very urgent: Seriously ill or injured patients whose lives are not in immediate danger \\
\hline 3 & Urgent: patients with serious problems, but apparently stable condition \\
\hline 4 & $\begin{array}{l}\text { Standard: Standard Accident and Emergency (A\&E) cases without immediate danger } \\
\text { or distress }\end{array}$ \\
\hline 5 & Non-urgent: patients whose conditions are not true accidents or emergencies \\
\hline
\end{tabular}

the curriculum of the Royal College of Emergency Physicians requires level 1 ultrasound competencies, which include echocardiography in life support where a FoCUS scan is delivered [3]. Accordingly, emergency department registrars and consultants are trained in the basic echo views required to identify significant life-threatening pathologies that pocketsized point-of-care systems are designed for. More widespread use of FoCUS as an extension of clinical examination as recommended [11] will improve the skill set in this group of professionals and potentially reduce the number of misdiagnosed patients.

\section{Objective}

In the PEEDED study we seek to assess the effect on time to diagnosis when using early pocket-sized echo in patients attending the emergency department with acute dyspnoea. We hypothesized that the addition of cardiac imaging with a pocket-size ultrasound system (Vscan) would provide rapid diagnostic information as an extension of clinical examination.

\begin{tabular}{ll|l|}
$\begin{array}{l}\text { Table } 2 \\
\text { graphics }\end{array}$ & PEEDED study group demo- \\
\hline & $\begin{array}{l}\text { VScan } \\
\text { group } \\
(\boldsymbol{n}=\mathbf{2 1 )}\end{array}$ & $\begin{array}{l}\text { Control } \\
\text { group } \\
(\boldsymbol{n}=\mathbf{1 9})\end{array}$ \\
\hline $\begin{array}{l}\text { Age (years; median) } \\
\text { Gender }\end{array}$ & 64 & 65 \\
\hline $\begin{array}{l}\text { Male } \\
\text { Female }\end{array}$ & $62 \%$ & $47 \%$ \\
\hline
\end{tabular}




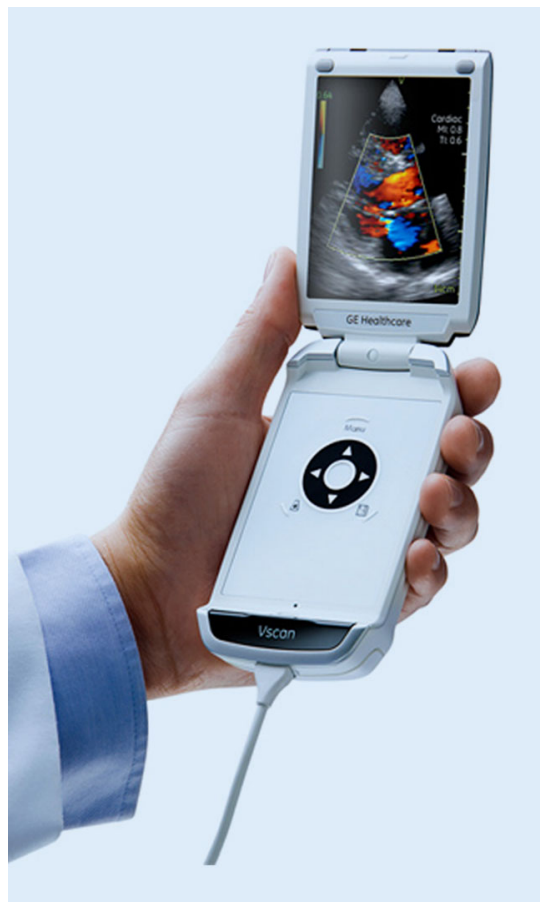

Fig. $1 \Delta$ VSCAN. (With permission from GE Healthcare)

\section{Methods}

\section{Study population and design}

This was a prospective blinded observational feasibility study that was carried out at a busy inner London emergency department at St Mary's Hospital, Paddington, UK. St Mary's Hospital is a general acute hospital with an accident and emergency department seeing over 41,000 attendances a year and is one of London's four major trauma centres. Adult patients with respiratory symptoms are generally admitted through the emergency department arriving by ambulance, selfpresenting or referred by general practitioners or outpatient clinics. Acute shortness of breath contributes around $8 \%$ of attendances with approximately 270 attendances a month.

Patients included were adults over the age of 18 who attended the emergency department by any means with a presenting complaint including shortness of breath.

Inclusion criteria:

- Adult patients over 18 years of age,

- Nontrauma,

- Shortness of breath/dyspnoea as part of presenting complaint,
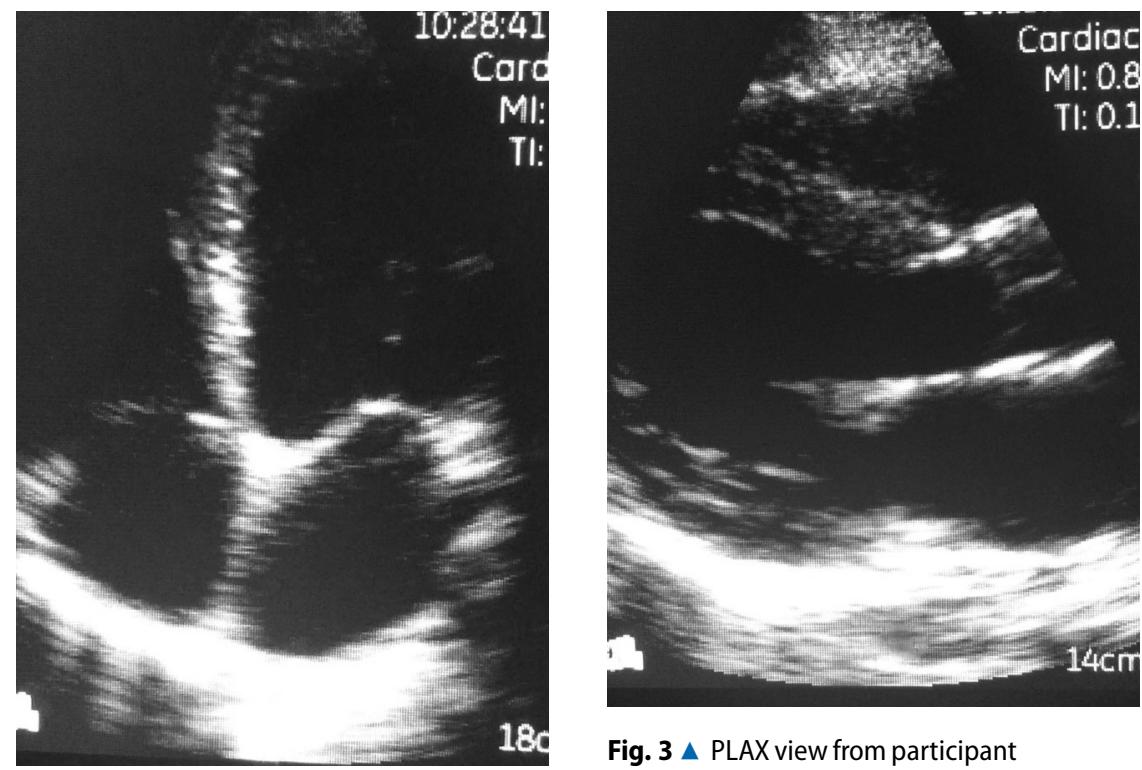

Fig. $2 \Delta$ Apical 4-chamber view from participant

- Majors (major illness area) or resuscitaton area patients (triage category 1-3) see • Table 1; [12, $13]$.

\section{Recruitment and consent}

Appropriate patients were identified at triage by the emergency department care team and asked for consent for the research team to approach. Written consent was obtained from all patients included. Patients with temporary lack of capacity due to being acutely unwell were included where appropriate personal or professional assent could be obtained and retrospective consent was obtained when capacity was restored. Where loss of capacity was permanent patients were excluded.

\section{Randomisation}

Each patient was assigned a number from a random number generator. Those with an even number were included in the scan group and those receiving an odd number in the control group.

\section{Devices}

The pocket-sized cardiac ultrasound scans were performed using the Vscan device by GE Systems (• Fig. 1).
Fig. 3 ॥ PLAX view from participant

\section{Procedures and outcomes}

Those patients recruited to the Vscan group received a FoCUS scan of less than 10 min duration. Results for this were recorded in a reporting sheet adapted from the a previous trial using Vscan (the POPPET trial [14]). This sheet was placed in the patient case card. In addition to this an algorithm, adapted from Emergency Echocardiography by Adrian Chenzbraun [15], was completed if major diagnostic findings were found. The reviewing physician was asked to complete a proforma recording:

- The presumptive diagnosis,

- Time of diagnosis,

- Treatment given,

- Time of treatment.

The patients were followed up by the researchers via their electronic patient records to collect data on:

- Final diagnosis,

- Length of stay,

- Inpatient mortality,

- 30 day mortality.

A sample size of 40 patients was used based on recommendations in the Imperial College feasibility assessment. 
Herz 2017· 42:255-261 DOI 10.1007/s00059-016-4531-4

(c) Springer Medizin Verlag GmbH 2017

\section{A. Colclough · P. Nihoyannopoulos}

\section{Pocket-sized point-of-care cardiac ultrasound devices. Role in the emergency department}

\section{Abstract}

Background. Acute breathlessness accounts for $8 \%$ of accident and emergency attendances. Point-of-care cardiac ultrasound (US) effectively reduces time to diagnosis. Fast and practical information via pocket-sized cardiac US devices may better the diagnosis in this complex patient group.

Methods. We prospectively enrolled 40 consecutive patients presenting with shortness of breath at the emergency department (ED). Divided into two groups were all adult patients over 18 with acute breathing difficulties (triage category 1-3): 21 patients received a short focused cardiac US scan using a pocket-sized Vscan and 19 patients received no scan. Data were obtained regarding the time taken for diagnosis and treatment, patient length of stay, inpatient mortality and 30-day mortality.

Results. In the scanned group 33\% of patients had significantly abnormal Vscan results that had the potential to aid diagnosis and guide management. The difference of $20 \mathrm{~min}$ between the means of the time to diagnosis between the groups was not significant. Discussion. The individual knowledge of UK emergency physicians regarding basic echocardiography varies greatly. An intuitive approach following a brief tutorial on pocketsize echocardiography was shown to improve diagnostic accuracy in addition to history taking and physical examination by medical students and junior doctors with no previous exposure to echocardiography. Increasing evidence shows the feasibility and benefit of FOCUS echo in the ED and the pocket-sized devices could play a large role.

Conclusion. The Vscan is a practical, portable device that provides rapid diagnostic information. One third of patients had significant findings on the scans to possibly aid diagnosis and prevent misdiagnosis. This has the potential to reduce time to diagnosis in the ED.

Keywords

Dyspnea - Echocardiography · Diagnosis, differential $\cdot$ Ultrasound $\cdot$ Vscan

\section{Ultraschallgeräte im Taschenformat für die kardiale Point-of-care-Versorgung. Bedeutung in der Notaufnahme}

\section{Zusammenfassung}

Hintergrund. Bei $8 \%$ der Unfall- und Notfallbehandlungen liegt eine akute Atemnot zugrunde. Eine kardiale Point-ofcare-Sonographie reduziert die Zeit bis zur Diagnose effektiv. Schnelle und praktische Informationen, die durch ein Ultraschallgerät im Taschenformat zur Verfügung gestellt werden, können die Diagnosestellung bei dieser komplexen Patientengruppe verbessern.

Methoden. Insgesamt wurden 40 Patienten, die sich mit Atemnot in der Notaufnahme vorstellten, prospektiv in die Studie eingeschlossen. Alle erwachsenen Patienten über 18 Jahre mit akuten Atemproblemen (Triage-Kategorie 1-3) wurden in 2 Gruppen unterteilt: 21 Patienten, die einen kurzen fokussierten Herzultraschall mit einem Vscan im Taschenformat erhielten, und 19 Patienten, die keinen Scan erhielten. Es wurden Daten bezüglich der Zeit bis zur Diagnose und Behandlung, der Hospitalisationsdauer, Krankenhausmortalität und 30-TageMortalität erhoben.

Ergebnisse. In der Vscan-Gruppe hatten $33 \%$ der Patienten signifikant abnormale Vscan-Ergebnisse, die das Potenzial hatten, bei der Diagnosestellung zu helfen und die richtige Behandlung zu finden. Die Differenz von 20 min zwischen den Mittelwerten der Diagnosezeit in den beiden Gruppen war nicht signifikant.

Diskussion. Der individuelle Kenntnisstand der Notfallärzte in Großbritannien weist große Unterschiede auf. Ein intuitives Vorgehen nach einem kurzen Lehrgang zum EKG im
Taschenformat hat die diagnostische Präzision bei Medizinstudierenden und Assistenzärzten ohne vorherige EKG-Erfahrung verbessert. Die steigende Evidenz zeigt die Machbarkeit und Vorteile der fokussierten Sonographie in der Notaufnahme. Die Geräte im Taschenformat könnten hier eine große Rolle spielen. Schlussfolgerung. Der Vscan stellte sich als praktisches, mobiles Gerät dar, das schnell diagnostische Informationen lieferte. Ein Drittel der Patienten hatten im Rahmen der Scans signifikante Befunde, die das Potenzial hatten, die Zeit bis zur Diagnose in der Notaufnahme zu verbessern.

Schlüsselwörter Dyspnoe - Echokardiographie - Differenzialdiagnose $\cdot$ Ultraschall. Vscan

\section{Quality control}

The images acquired from the 21 Vscans obtained were reviewed by three further echocardiographers (one cardiology registrar and two cardiac physiologists) who were asked to complete the same reporting sheet.

\section{Medical ethics}

All procedures followed were in accordance with the ethical standards of the responsible commitee on human experimentation (institutional and national) and with the Helsinki declaration of 1975 , as revised in 2008. Informed consent was obtained from all patients for being included in the study. The project was given a favourable opinion by:
- Ethics committee: Wales REC7,

- REC reference: 16/wa/0158,

- HRA approval: IRAS 199156.

\section{Results}

In all, 52 patients were approached for recruitment over a period of 10 days in the emergency department. Eleven (21\%) declined to participate. Twenty one patients were recruited in the scan group and 20 patients were recruited to the 


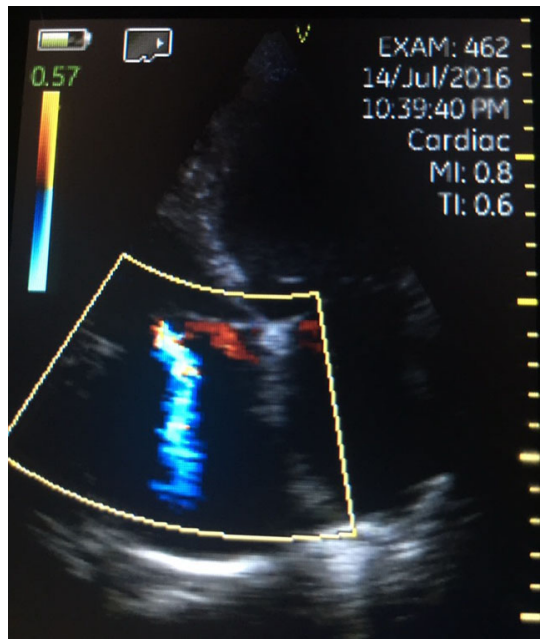

Fig. 4 \ Apical 4-chamber view with colour Doppler demonstrating tricuspid regurgitation

control group. One patient in the control group withdrew informed consent after inclusion in the study. No patients withdrew from the study due to adverse events or complications. Forty patients remained in the study in total, 21 in the scan group, 19 in the control group.

Demographics of the two groups are summarised in $\bullet$ Table 2.

\section{Quality control}

Following quality control there was $96 \%$ concordance with reports by other interpreters. No results were found to be underestimated in severity.

\section{Patient data}

Of the 21 patients who received a Vscan, $7(33 \%)$ had significant findings falling into the categories of the algorithm (tamponade $[n=0]$, moderate to severe LVSD [ $n=5]$, enlarged poorly contracting RV [ $n=2]$, significant valvular disease [moderate or severe, $n=5$ ]) (- Table 3; - Fig. 2, 3, 4 and 5).

Of the recruited patients, 9 received a Vscan by a cardiologist later in their admission and one a departmental echo. Of the five scanned in the ED as part of the intervention group, four Vscans concurred with ED scan results. The 5th cardiologist Vscan reported a patient's mitral regurgitation as mild rather than moderate as estimated in the emergency department scan. Two showed severely impaired LV
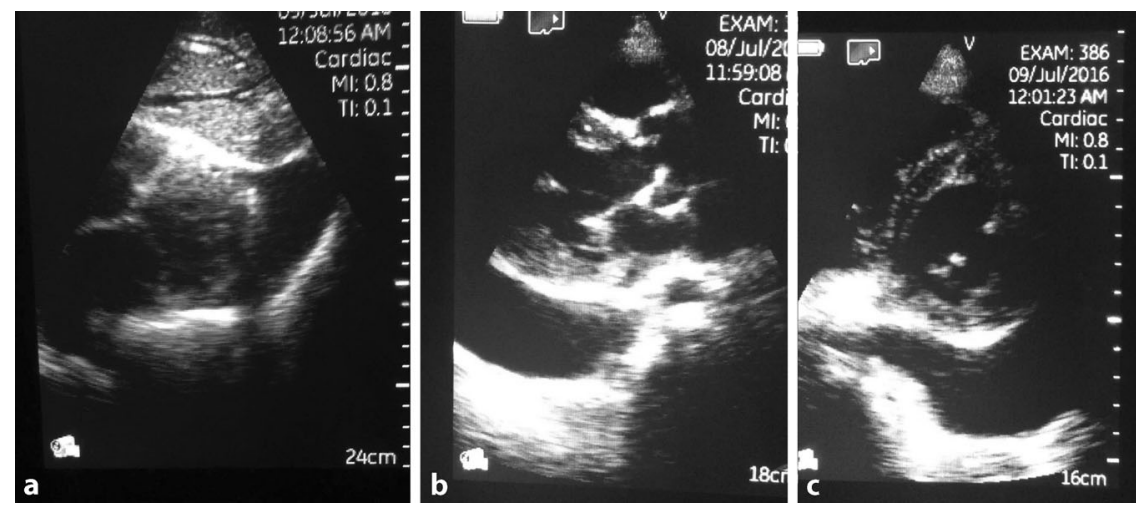

Fig. 5a-c $\Delta$ Images acquired via Vscan from a patient with severe left ventricular systolic dysfunction and a pleural effusion. There was discrepancy within the quality control image interpreters as to whether this was pericardial effusion. Images were reviewed by a consultant cardiologist at the time of acquisition to confirm this was a pleural effusion

systolic function, one showed a new area of hypokinesis and the other had inadequate images obtained due to poor acoustic windows.

\section{Time to diagnosis}

The median time to diagnosis from the time first seen by the clinician was $40 \mathrm{~min}$ in the scanned group and $60 \mathrm{~min}$ in the control group. Using the Mann-Whitney $U$ test this difference is not significant at $P<0.05$ (U-value 142 , Z-score $-1.54379)$ (• Fig. 6).

\section{Diagnoses}

A breakdown of the final diagnosis on discharge is shown in $\bullet$ Table 4.

\section{Time to treatment}

The median time to treatment for those that required treatment was $55.5 \mathrm{~min}$ (70 min scan group, 49 min control) with three people having treatment on triage or from the London Ambulance Service before review by clinician. Eight patients did not require any treatment within the emergency department. Median time to referral was $61 \mathrm{~min}(60 \mathrm{~min}$ scan group, $64 \mathrm{~min}$ control). Thirteen patients did not require referral.

\section{Length of hospital stay}

Median length of stay in the two groups was 1 day (both groups 1 day), mean was 3.7 days (4.85 days scan group, 2.47 days control).

\section{Mortality}

Inpatient mortality was zero. Two patients died in the 30-day follow-up period both in the theoretical control group and both from apparent cardiac-related causes.

\section{Discussion}

In this feasibility study we showed that the addition of cardiac imaging in the emergency department using a Vscan provides useful information in a short period of time. Seven scanned patients (33\%) had significantly abnormal scans helping guide diagnosis and management.

The Vscan was a user friendly practical device that allowed a focused cardiac study to be carried out in less than $10 \mathrm{~min}$ in all included patients in order to identify the significant abnormalities as defined in the algorithm. It is light, portable and small enough to fit into scrub pockets. Battery life was good with a full charge allowing over 10 scans a day with additional image reviews. Another benefit was the ability to take the device to show colleagues or specialists the images without time-consuming uploads. 

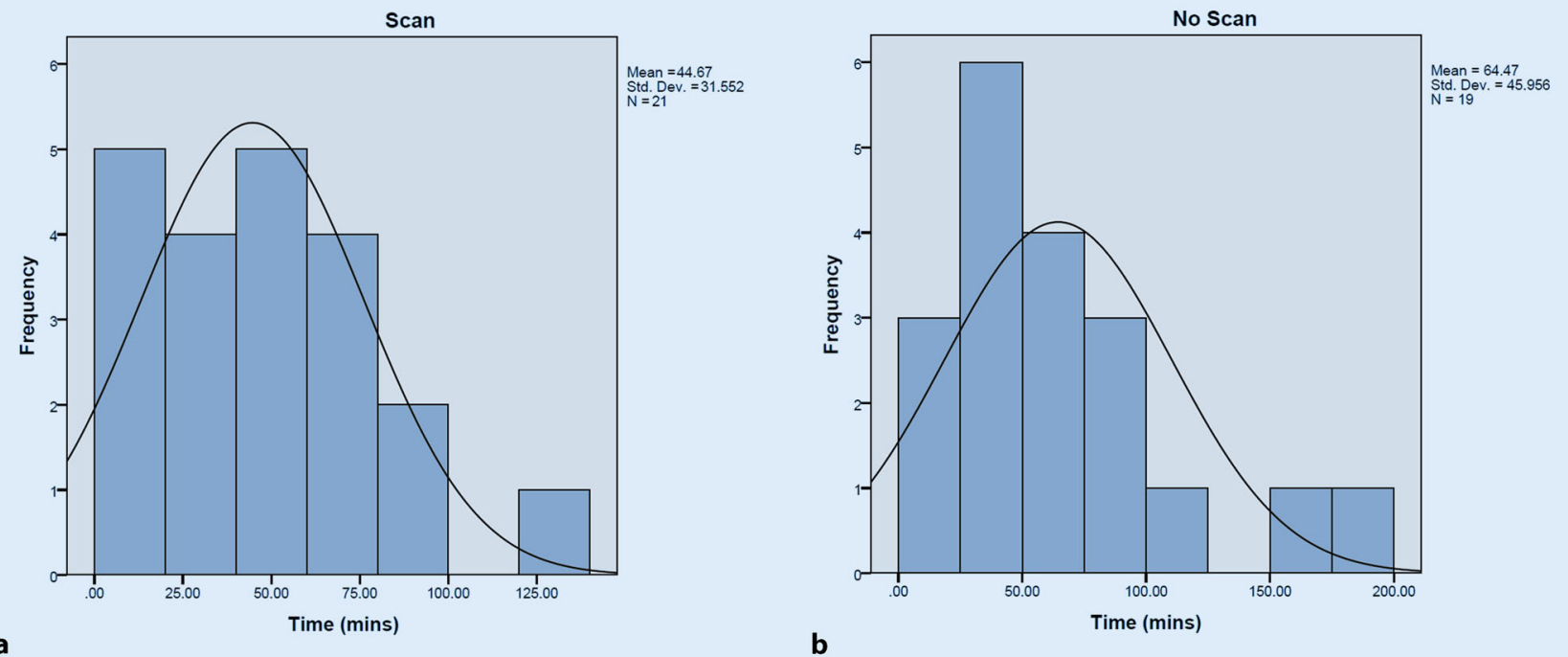

a

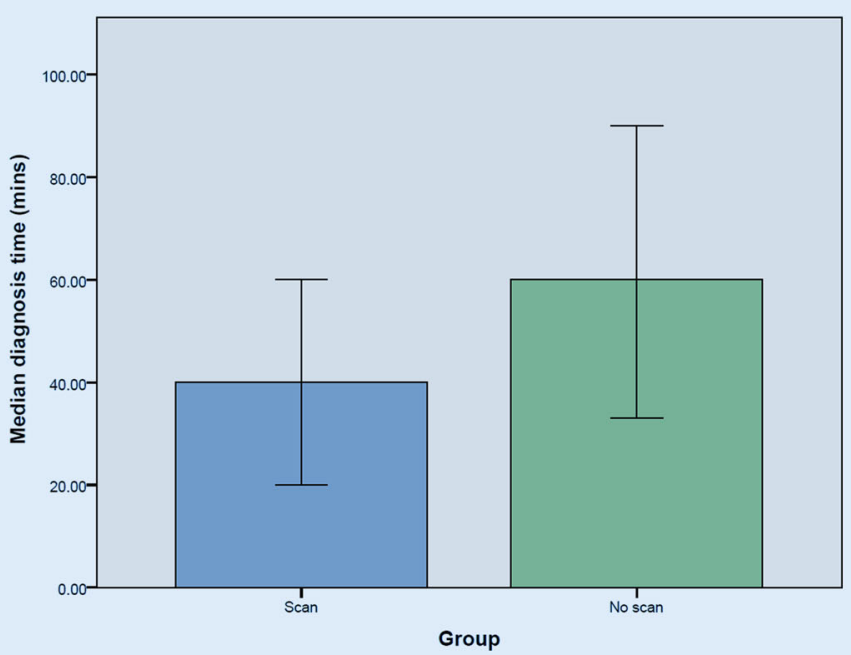

Fig. 6 ム Data distribution for primary outcome data: a Histogram showing time to diagnosis in scan group b Histogram showing time to diagnosis in non-scan group, both demonstrating non normally distributed data. cBoxand whisker plot comparing median time to diagnosis for scan and non scan groups

The images were of good quality, and the image optimisation functions were adequate for this study although the maximum depth available was a problem in some of the larger patients. The scans were well tolerated by patients and most were enthusiastic about having the additional test.

The patient group studied was broad with the only clinical criterion being breathlessness as part of the presenting complaint. It became apparent during recruitment that patients reported shortness of breath less readily than symptoms such as chest pain, fever or cough despite it being clinically appar- ent. Consequently, some patients were not included who were later deemed by the clinician to have significant dyspnoea on examination. A previous study by Laursen et al. [10] placed less emphasis on expressed breathlessness as a symptom or perceived breathlessness at triage or by ambulance staff, but more on physiological parameters (in this case saturations less than 95\%, oxygen therapy commenced or a respiratory rate over 20) followed by a broader definition of "respiratory symptoms" including present or recent cough, chest pain or dyspnoea in addition to those physiological parameters. As a relatively large proportion of the patients included in the study group were well enough to be discharged from the emergency department without follow-up, it would be helpful to add measures to include a more unwell patient group with abnormal physiological parameters being a logical step in place of triage categories and patient presenting complaint. We included triage category 1-3 patients; these categories are assigned by the triage nurses and in practice when reviewed by the clinician it appeared many of the patients included would fall into some of the less urgent categories 4-5. 


\section{Table 3 Abnormal VScan findings}

\begin{tabular}{|c|c|}
\hline $\begin{array}{l}\text { Focused sonography find- } \\
\text { ings }\end{array}$ & $\begin{array}{l}\text { Value } \\
(n=21)\end{array}$ \\
\hline LVH moderate or severe & $2(9 \%)$ \\
\hline $\begin{array}{l}\text { LV systolic function moder- } \\
\text { ately impaired }\end{array}$ & $2(9 \%)$ \\
\hline $\begin{array}{l}\text { LV systolic function severely } \\
\text { impaired }\end{array}$ & $3(14 \%)$ \\
\hline LV moderate/severely dilated & $2(9 \%)$ \\
\hline LA dilated & $2(9 \%)$ \\
\hline RV systolic function impaired & $2(9 \%)$ \\
\hline RV dilated & $2(9 \%)$ \\
\hline RA dilated & $2(9 \%)$ \\
\hline AS-moderate or severe & $1(4 \%)$ \\
\hline AR-moderate or severe & $1(4 \%)$ \\
\hline MS-moderate or severe & $0(0 \%)$ \\
\hline MR-moderate or severe & $2(9 \%)$ \\
\hline TR-moderate or severe & $3(14 \%)$ \\
\hline PR-moderate or severe & 0 \\
\hline Aortic root dilated & 0 \\
\hline Pericardial effusion & 0 \\
\hline Pleural effusion & $1(4 \%)$ \\
\hline RAP pressure raised & $1(4 \%)$ \\
\hline Obvious RWMA & $1(4 \%)$ \\
\hline \multicolumn{2}{|c|}{$\begin{array}{l}L V H \text { left ventricular hypertrophy, } L V \text { left } \\
\text { ventricle, } L A \text { left atrium, } R V \text { right ventricle, } \\
R A \text { right atrium, } A S \text { aortic stenosis, } A R \text { aortic } \\
\text { regurgitation, } M S \text { mitral stenosis, } M R \text { mitral } \\
\text { regurgitation, } T R \text { tricuspid regurgitation, } \\
P R \text { pulmonary regurgitation, } R A P \text { right } \\
\text { atrial pressure, } R W M A \text { regional wall motion } \\
\text { abnormality }\end{array}$} \\
\hline
\end{tabular}

The primary outcome measure was time to diagnosis. In this study we based this time in minutes on the time from the clinician's first encounter with the patient to when they considered a diagnosis had been made. On collecting this data for both groups it was apparent that it was rather subjective and the exact time was difficult to ascertain. In some cases investigations such as chest X-rays and blood tests had been pre-ordered by other clinical staff allowing these results to be taken into consideration which clearly leads to faster diagnosis. Moreover, there was large variation among patients in this head start effect. Future studies should focus on patients admitted directly to the resuscitation room, who are seen on arrival facilitating the clinician to perform a Vscan in parallel with other investigations whilst also allowing for the time of clinician's first contact to be well defined.
Table 4 Final diagnoses

\begin{tabular}{l|l}
\hline Final diagnosis & $\begin{array}{l}\text { Number of } \\
\text { patients }\end{array}$ \\
\hline Fast atrial fibrillation & $2(5 \%)$ \\
\hline Fast AF and pleural effusion & $1(2.5 \%)$ \\
\hline Bronchiectasis & $1(2.5 \%)$ \\
\hline Anxiety & $3(7.5 \%)$ \\
\hline Sepsis and cardiac failure & $1(2.5 \%)$ \\
\hline COPD & $7(17.5 \%)$ \\
\hline Pneumonia & $4(10 \%)$ \\
\hline $\begin{array}{l}\text { Allergic broncho- } \\
\text { aspergillosis }\end{array}$ & $1(2.5 \%)$ \\
\hline $\begin{array}{l}\text { SLE } \\
\text { COPD and CCF }\end{array}$ & $1(2.5 \%)$ \\
\hline Vasovagal & $1(2.5 \%)$ \\
\hline $\begin{array}{l}\text { Viral induced wheeze } \\
\text { Crescendo angina }\end{array}$ & $1(2.5 \%)$ \\
\hline Asthma & $1(2.5 \%)$ \\
\hline Measles & $1(2.5 \%)$ \\
\hline ACS & $6(15 \%)$ \\
\hline Hyperventilation & $1(2.5 \%)$ \\
\hline $\begin{array}{l}\text { Musculoskeletal chest pain } \\
\text { causing dyspnoea }\end{array}$ & $1(2.5 \%)$ \\
\hline No abnormality found & $2(5 \%)$ \\
\hline $\begin{array}{l}\text { AF atrial fibrillation, COPD chronic obstruc- } \\
\text { tive pulmonary disease, SLE systemic lupus } \\
\text { erythematosus, CCF congestive cardiac } \\
\text { failure, ACS acute coronary syndrome }\end{array}$ \\
\hline
\end{tabular}

The secondary outcome measures such as time to treatment, length of stay and mortality were more straight forward to collect with electronic tracking and should be included to ascertain possible longer term implications of early pocketsized echo and cost effectiveness.

The progression to a full randomised controlled trial with a larger sample size is a logical next step. Our primary outcome measure should remain as time to diagnosis with a null hypothesis that an early pocket-sized echo in the emergency department does not lead to a faster diagnosis.

With a difference on means of $20 \mathrm{~min}$ between the times to diagnosis of the groups a sample size of 76 would be needed to show significance with a power of 0.8 and $5 \%$ error rate.

Currently UK emergency physicians are trained in echocardiography in terms of "Echo in Life support" as part of their level 1 ultrasound training. The requirements for this are quite basic; subsequently there is a great variation amongst individual physician's skill levels in echo image acquisition and interpretation. This is multifactorial: A lack of training opportunities, a lack of experienced operators to supervise, time constraints in the emergency setting and impractical equipment. Our colleagues in intensive care manage a similar subset of patients and are using point-of-care echocardiography to a much greater extent with many physicians striving for BSE accreditation. We have previously demonstrated that an intuitive approach following a brief tutorial on pocketsize echocardiography can improve the diagnostic accuracy over and above history taking and physical examination in the hands of medical students and junior doctors with no previous exposure to echocardiography [16]. As more evidence is obtained to show the feasibility and benefit of FOCUS echo in the emergency department this is likely to change and the pocket-sized devices could potentially play a large role in converting those who find our larger machines impractical and their set up time consuming. A project such as the one we suggest would be another step towards demonstrating some of its applications and benefits and as a result training opportunities and echo experienced physicians may become more prevalent.

\section{Conclusions}

In this feasibility study we showed that the use of a Vscan in the emergency department was a practical, portable device that provided rapid diagnostic information as an extension of clinical examination. This has the potential to reduce time to diagnosis in this time pressured environment. 


\section{Corresponding address}

\section{Dr. A. Colclough}

Emergency Department, Kings College Hospital SE5 9RS Denmark Hill, London, UK annacolclough@nhs.net

\section{Prof. P. Nihoyannopoulos}

Hammersmith Hospital

Du Cane Road, W120HS London, UK

Petros@imperial.ac.uk

\section{Compliance with ethical guidelines}

Conflict of interest. A. Colclough and P. Nihoyannopoulos declare that they have no competing interests.

All procedures followed were in accordance with the ethical standards of the responsible commitee on human experimentation (institutional and national) and with the Helsinki declaration of 1975, as revised in 2008. Informed consent was obtained from all patients for being included in the study.

\section{References}

1. Azeemuddin A, Graber MA (2016) Evaluation of the adult with dyspnea in the emergency department In: Hockberger RS (ed) UpToDate. http://www. uptodate.com/home

2. Woollard M, Greaves I (2004) 4 shortness of breath Emerg Med J 21(3):341-350

3. The Royal College Of Emergency Medicine. Curriculum and Assessment Systems For Training in Emergency Medicine. https://www.rcem.ac. uk/docs/Training/RCEM. Accessed 16. December 2016

4. Ray P, Birolleau S, Lefort $Y$ et al (2006) Acute respiratory failure in the elderly: etiology, emergency diagnosis and prognosis. Crit Care 10(3):R82. doi:10.1186/cc4926

5. Combes A, Mokhtari M, Couvelard A et al (2004) Clinical and autopsy diagnoses in the intensive care unit: a prospective study. Arch Intern Med 164(4):389-392

6. Mandavia DP, Hoffner RJ, Mahaney K, Henderson SO (2001) Bedside echocardiography by emergency physicians. Ann Emerg Med 38(4):377-382

7. Arntfield RT, Millington SJ (2012) Point of care cardiac ultrasound applications in the emergency department and intensive care unit - a review. Curr Cardiol Rev 8(2):98-108

8. Mandavia DP, Aragona J, Chan L et al (2000) Ultrasound training for emergency physicians - a prospective study. Acad Emerg Med 7(9):1008-1014

9. Labovitz AJ, Noble VE, Bierig Metal (2010) Focused cardiac ultrasound in the emergent setting: a consensus statement of the American Society of Echocardiography and American College of Emergency Physicians. J Am Soc Echocardiogr 23(12):1225-1230

10. Laursen CB, Sloth E, Lassen AT et al (2014) Pointof-care ultrasonography in patients admitted with respiratory symptoms: a single-blind, randomised controlled trial. Lancet Respir Med 2(8):638-646
11. Sicari R, Galderisi M, Voigt JU et al (2011) The use of pocket-size imaging devices: a position statement of the European Association of Echocardiography. Eur JEchocardiogr 12(2):85-87

12. Marrow J(1998) Triage and casemix in accident and emergency medicine. Eur JEmerg Med 5(1):53-58

13. A ANDE Initial Triage Assessment Category. http:// www.datadictionary.nhs.uk/data_dictionary/ attributes/a/a_and_e_initial_assessment triage_category_de.asp?shownav=1: NHS 2016. Accessed 16. December 2016

14. Preoperative Pocket Echocardiography Trial (POPPET). https://clinicaltrials.gov/ct2/show/ NCT02589808. Accessed 16. December 2016

15. Chenzbraun A (2009) Emergency echocardiography. Springer, London

16. Panoulas VF, Daigeler AL, Malaweera AS (2013) Pocket-size hand-held cardiac ultrasound as an adjunct to clinical examination in the hands of medical students and junior doctors. Eur Heart $J$ Cardiovasc Imaging 14(4):323-330

\section{Neuer Mechanismus zur \\ Behandlung von Bluthochdruck entdeckt}

Eine Forschergruppe des Zentrums für Kardiologie und des Centrums für Thrombose und Hämostase (CTH) an der Universitätsmedizin Mainz entdeckte jetzt eine bisher unbekannte Interaktion von Faktoren der Blutgerinnung und der Entzündungsreaktion. Im Rahmen der Studie verabreichte die Forschergruppe im Tiermodell das blutdrucksteigernde Hormon Angiotensin II. Es zeigte sich, dass Angiotensin II in der Gefäßwand eine Entzündungsreaktion auslöst, die durch Komponenten des Blutgerinnungssystems maßgeblich verstärkt wird. Die Wissenschaftler fanden heraus, dass der Blutgerinnungsfaktor XI für den Anstieg dieser Entzündungsreaktion verantwortlich ist. Eigentliche Aufgabe des Blutgerinnungsfaktors $\mathrm{XI}$ ist es, die Aktivierung der Gerinnung auf der Oberfläche der Blutplättchen anzutreiben. Er wird dabei von Oberflächenrezeptoren der Blutplättchen unterstützt. Hemmt man XI, dann lässt sich der Bluthochdruck deutlich senken, und es treten weniger Entzündungsreaktionen auf. Die Hemmung dieses Gerinnungsfaktors, der bekanntermaßen nur eine untergeordnete Rolle bei der normalen Blutstillung spielt, konnte sogar eine Nierenschädigung deutlich reduzieren. Die anschließende Untersuchung von Patientenproben zeigte ebenfalls deutliche Hinweise für eine verstärkte Gerinnungsaktivierung auf den Blutplättchen in Patienten mit erhöhtem Blutdruck. Auch hier war der Blutgerinnungsfaktor XI die treibende Kraft, wie die Wissenschaftler nachweisen konnten. Diese Erkenntnisse legen nah, dass eine medikamentöse Hemmung des Blutgerinnungsfaktor XI Bluthochdruckpatienten helfen könnte. Die Ergebnisse wurden in der Fachzeitschrift ,Science Translational Medicine' veröffentlicht.

Literatur: Kossmann et al. (2017) Plateletlocalized FXI promotes a vascular coagulation-inflammatory circuit in arterial hypertension, Sci. Transl. Med. 9, Issue 375, DOI: 10.1126/scitransImed.aah4923

Quelle: Universitätsmedizin der Johannes Gutenberg-Universität Mainz, www.unimedizin-mainz.de/ 